\title{
Low-Temperature Destruction of Carbon Tetrachloride over Lanthanide Oxide-Based Catalysts: From Destructive Adsorption to a Catalytic Reaction Cycle
}

\author{
Pieter Van der Avert, ${ }^{[a]}$ Simon G. Podkolzin, ${ }^{[c]}$ Olga Manoilova, ${ }^{[b]}$ \\ Hendrik de Winne, ${ }^{[a]}$ and Bert M. Weckhuysen*[a,b]
}

\begin{abstract}
The catalytic destruction of carbon tetrachloride in the presence of steam, $\quad \mathrm{CCl}_{4}+2 \mathrm{H}_{2} \mathrm{O} \rightarrow 4 \mathrm{HCl}+\mathrm{CO}_{2}$, was investigated at $200-350{ }^{\circ} \mathrm{C}$ over a series of lanthanide (La, Ce, $\mathrm{Pr}$ and $\mathrm{Nd})$ and alkaline-earth metal $(\mathrm{Mg}, \mathrm{Ca}$, $\mathrm{Sr}$ and $\mathrm{Ba}$ ) oxide-based catalysts with kinetic experiments, Raman spectroscopy, X-ray photoelectron spectroscopy, IR spectroscopy, X-ray diffraction, and DFT calculations. This new catalytic reaction was achieved by combining destructive adsorption of $\mathrm{CCl}_{4}$ on a basic oxide surface and concurrent dechlorination of the resulting partially chlorinated solid by steam. The combination of the two noncatalytic reactions
\end{abstract}

into a catalytic cycle provided a rare opportunity in heterogeneous catalysis for studying the nature and extent of surface participation in the overall reaction chemistry. The reaction is proposed to proceed over a terminal lattice oxygen site with stepwise donation of chlorine atoms from the hydrocarbon to the surface and formation of the gas-phase intermediate $\mathrm{COCl}_{2}$, which is readily readsorbed at the catalyst sur-

Keywords: adsorption • chlorohydrocarbons $\cdot$ density functional calculations $\cdot$ heterogeneous catalysis . lanthanides face to form $\mathrm{CO}_{2}$. In a second step, the active catalyst surface is regenerated by steam with formation of gas-phase $\mathrm{HCl}$. Depending on the reaction conditions, the catalytic material was found to transform dynamically from the metal oxide state to the metal oxide chloride or metal chloride state due to the bulk diffusion of oxygen and chlorine atoms. A catalyst obtained from a $10 \mathrm{wt} \% \mathrm{La}_{2} \mathrm{O}_{3} / \mathrm{Al}_{2} \mathrm{O}_{3}$ precursor exhibited the highest destruction rate: $0.289 \mathrm{~g}$ $\mathrm{CCl}_{4} \mathrm{~h}^{-1} \mathrm{~g}^{-1}$ catalyst at $350^{\circ} \mathrm{C}$, which is higher than that of any other reported catalyst system.

\section{Introduction}

Chlorinated hydrocarbons (CHCs) are persistent toxic compounds for which the environment has only little assimilative capacity ${ }^{[1]}$ The currently employed method of treatment is thermal incineration at temperatures above $1300^{\circ} \mathrm{C}^{[2]}$

[a] Dr. ir. P. Van der Avert, ir. H. de Winne,

Prof. Dr. ir. B. M. Weckhuysen

Centrum voor Oppervlaktechemie en Katalyse

Departement Interfasechemie, KULeuven

Kasteelpark Arenberg 23, 3001 Leuven (Belgium)

Fax: (+31)30-251-10-27

[b] Dr. O. Manoilova, Prof. Dr. ir. B. M. Weckhuysen Departement Anorganische Chemie en Katalyse Debye Instituut, Universiteit Utrecht Sorbonnelaan 16, 3584 CA Utrecht (The Netherlands)

[c] Dr. S. G. Podkolzin

Dow Chemical Company, Corporate Research Midland, MI 48674 (USA)
These high temperatures and the related costs provide a motivation to look for other (preferentially catalytic) solutions. Two main catalytic routes are reported in the literature. ${ }^{[3,4]}$ One is the oxidation of CHCs over supported noble metal catalysts. The drawback of this route is the deactivation of the noble metal by decomposition products such as $\mathrm{Cl}_{2}$ and $\mathrm{HCl}$. This problem can be (partially) solved by the use of transition metal oxides, although volatile transition metal oxide chlorides may be formed. The other catalytic option is hydrodechlorination, in which CHCs are transformed in the presence of hydrogen into alkanes and $\mathrm{HCl}$. Although this method has clear economic and environmental advantages, such as the use of reaction products and elimination of hazardous by-products (e.g., $\mathrm{Cl}_{2}$ and $\mathrm{COCl}_{2}$ ), it is not frequently used because known catalysts are unstable due to chlorine poisoning.

Another possible destruction method is based on the reaction of basic metal oxides with, for example, $\mathrm{CCl}_{4}$ to form $\mathrm{CO}_{2}$ and the corresponding metal chloride. This reaction, usually referred to as destructive adsorption, was pioneered by Klabunde et al. ${ }^{[5-7]}$ It is not a catalytic process since the 
metal oxide is gradually transformed into the metal chloride and, as a consequence, the exact nature of the transformations taking place in the destructive adsorbent could be studied by Raman and X-ray photoelectron spectroscopy. ${ }^{[8-10]}$ It was shown that the destruction rate for $\mathrm{CCl}_{4}$ parallels the basicity of the metal oxide (the destruction activity increases in the order $\mathrm{MgO}<\mathrm{CaO}<\mathrm{SrO}<\mathrm{BaO}$ ), and that unusual metal oxide chlorides were formed as solid reaction intermediates (e.g., $\mathrm{Ba}_{4} \mathrm{OCl}_{6}$ ).

This chemistry can be made catalytic if the state of the metal oxide surface, that is, the extent of surface chlorination, can be controlled during the destruction of $\mathrm{CCl}_{4}$ by addition of steam. Recently, we reported a new class of catalyst materials active in steam decomposition of $\mathrm{CCl}_{4} \cdot{ }^{[1,12]}$ Here we provide a detailed account of steam-dechlorination experiments on lanthanide oxide-based materials and show how a novel catalytic cycle was constructed on the basis of a fundamental understanding of the surface reactions. The fact that this catalytic process is a combination of two noncatalytic reactions provided a rare opportunity for studying the reaction mechanism. In this respect, this chemistry is rather unusual because typically in heterogeneous catalysis, the exact way in which the surface participates in the overall chemistry is difficult to determine. In addition to the mechanistic studies, we describe metal oxide catalysts that exhibit high activity and long-term stability in the catalytic dechlorination of $\mathrm{CCl}_{4}$ by steam. The catalytic results are compared with those of materials based on alkaline-earth metals.

\section{Results and Discussion}

From destructive adsorption towards a catalytic reaction cycle: Metal oxides, such as those of alkaline-earth metals and lanthanides, can destructively adsorb chlorinated hydrocarbons (e.g., $\mathrm{CCl}_{4}$ ) on their surface and, as a consequence of chlorine and oxygen diffusion in the bulk, are transformed gradually into the corresponding metal chlorides. ${ }^{[5-7]}$ This reaction can be written for $\mathrm{CCl}_{4}$ and $\mathrm{La}_{2} \mathrm{O}_{3}$ as Equation (1).

$3 / 2 \mathrm{CCl}_{4}+\mathrm{La}_{2} \mathrm{O}_{3} \rightarrow 2 \mathrm{LaCl}_{3}+3 / 2 \mathrm{CO}_{2}$

In previous papers we showed that 1) the efficiency of this destructive adsorption increases with increasing basicity of the metal oxide, and 2) the transformation is accompanied by the intermediate formation of metal oxide chlorides, ${ }^{[8-10]}$ for example, the unusual barium oxide chloride $\mathrm{Ba}_{4} \mathrm{OCl}_{6}$.

Figure 1 compares the destructive adsorption behavior of $\mathrm{La}_{2} \mathrm{O}_{3}, \mathrm{Pr}_{2} \mathrm{O}_{3}$, and $\mathrm{Nd}_{2} \mathrm{O}_{3}$ at $300^{\circ} \mathrm{C} .{ }^{[13]}$ The conversion is expressed as the percentage of the metal oxide transformed into the metal chloride after injecting $250 \mu \mathrm{L}$ of $\mathrm{CCl}_{4}$ in $\mathrm{He}$ at a molar $\mathrm{CCl}_{4}$ to metal oxide ratio of 20 . It can be seen that $\mathrm{La}_{2} \mathrm{O}_{3}, \mathrm{Pr}_{2} \mathrm{O}_{3}$, and $\mathrm{Nd}_{2} \mathrm{O}_{3}$ are partially transformed into $\mathrm{LaCl}_{3}, \mathrm{PrCl}_{3}$, and $\mathrm{NdCl}_{3}$, and $\mathrm{La}_{2} \mathrm{O}_{3}$ is the most active destructive adsorbent. Destructive adsorption can be turned into a catalytic process if the solids can be dechlorinated simultaneously with $\mathrm{CHC}$ conversion. One possible dechlorination route is steaming [Eq. (2)].

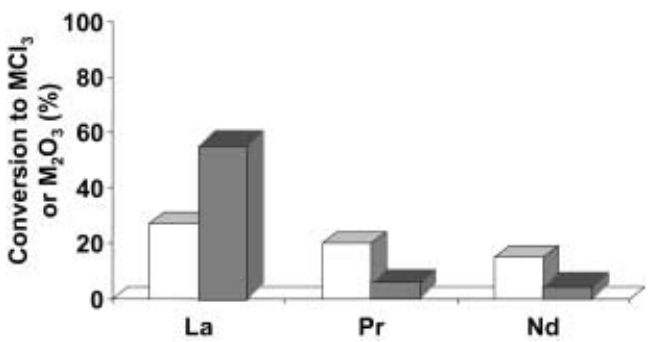

Figure 1. Destructive adsorption of $\mathrm{CCl}_{4}$ on lanthanide oxides at $300^{\circ} \mathrm{C}$. The efficiency of the process (white bars) is expressed as the percentage of the metal oxide transformed into the metal chloride after injecting $250 \mu \mathrm{L}$ of $\mathrm{CCl}_{4}$ in a $\mathrm{He}$ stream with a molar $\mathrm{CCl}_{4} /$ metal oxide ratio of 20 . Dechlorination of lanthanide chlorides at $300^{\circ} \mathrm{C}$ in the presence of steam. The efficiency of the process (gray bars) is expressed as the percentage of the metal chloride transformed into the metal oxide after steaming the metal chloride for $4 \mathrm{~h}$.

$2 \mathrm{LaCl}_{3}+3 \mathrm{H}_{2} \mathrm{O} \rightarrow \mathrm{La}_{2} \mathrm{O}_{3}+6 \mathrm{HCl}$

We tested dechlorination rates of $\mathrm{LaCl}_{3}, \mathrm{PrCl}_{3}$, and $\mathrm{NdCl}_{3}$ by treating these solids with steam for $4 \mathrm{~h}$ at $300^{\circ} \mathrm{C}$ (Figure 1). More than $50 \%$ of $\mathrm{LaCl}_{3}$ was converted to $\mathrm{La}_{2} \mathrm{O}_{3}$, whereas only relatively small amounts of $\mathrm{PrCl}_{3}$ and $\mathrm{NdCl}_{3}$ were transformed into the corresponding metal oxides. ${ }^{[13]}$ These results indicate that lanthanum oxide-based materials are potential catalysts for the overall reaction [Eq. (3)].

$\mathrm{CCl}_{4}+2 \mathrm{H}_{2} \mathrm{O} \rightarrow 4 \mathrm{HCl}+\mathrm{CO}_{2}$

The catalytic activity of $\mathrm{La}_{2} \mathrm{O}_{3}$ in reaction (3) as a function of reaction temperature is presented in Figure 2. The reaction started at about $250^{\circ} \mathrm{C}$, and the conversion, which

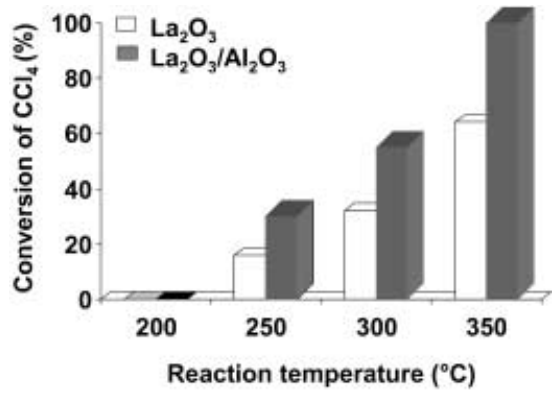

Figure 2. $\mathrm{CCl}_{4}$ conversion with steam $\left(\mathrm{H}_{2} \mathrm{O} / \mathrm{CCl}_{4}\right.$ feed molar ratio of 61$)$ after $7 \mathrm{~h}$ on stream as a function of reaction temperature for $\mathrm{La}_{2} \mathrm{O}_{3}$ (white bars) and $10 \mathrm{wt} \% \mathrm{La}_{2} \mathrm{O}_{3} / \mathrm{Al}_{2} \mathrm{O}_{3}$ (black bars).

steadily increased with increasing temperature, reached $62 \%$ at $350{ }^{\circ} \mathrm{C}$. Consistently higher conversions at temperatures above $250^{\circ} \mathrm{C}$ were observed for $10 \mathrm{wt} \% \mathrm{La}_{2} \mathrm{O}_{3}$ supported on alumina (Figure 2). The lowest reaction temperatures for bulk and supported $\mathrm{La}_{2} \mathrm{O}_{3}$ are similar. Therefore, it is likely that the reaction mechanism and corresponding energetics are also similar, and the difference in conversion can simply be attributed to a larger number of active sites per unit weight due to the higher surface area of the sup- 
ported catalyst. ${ }^{[14]}$ The conversion over $10 \mathrm{wt} \% \mathrm{La}_{2} \mathrm{O}_{3} / \mathrm{Al}_{2} \mathrm{O}_{3}$ catalyst reached $100 \%$ at $350{ }^{\circ} \mathrm{C}$ (Figure 2), which corresponds to a destruction rate of $0.289 \mathrm{~g} \mathrm{CCl}_{4} \mathrm{~h}^{-1} \mathrm{~g}^{-1}$ catalyst. This value is higher than that of any other reported catalyst system. ${ }^{[11,12,16]}$ For example, $\mathrm{Pt}, \mathrm{Pd}$, and $\mathrm{Rh} / \mathrm{TiO}_{2}$ catalysts, which are the most active $\mathrm{CHC}$-destruction catalysts reported, have a destruction rate of $0.102 \mathrm{~g} \mathrm{CCl}_{4} \mathrm{~h}^{-1} \mathrm{~g}^{-1}$ catalyst at $350^{\circ} \mathrm{C}^{[15]}$ Although comparison is not easy because of the different experimental conditions used, the destruction rate of the present catalyst under study is superior to those of existing oxidation catalysts.

The lanthanum-oxide-based materials exhibit long-term activity in the presence of steam (Figure 3), and this con-

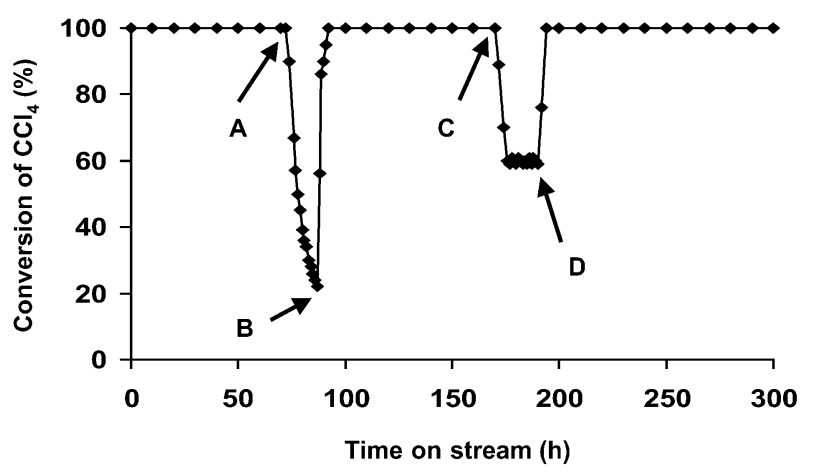

Figure 3. $\mathrm{CCl}_{4}$ conversion over $10 \mathrm{wt} \% \mathrm{La}_{2} \mathrm{O}_{3} / \mathrm{Al}_{2} \mathrm{O}_{3}$ at $350{ }^{\circ} \mathrm{C}$ with a $\mathrm{H}_{2} \mathrm{O} / \mathrm{CCl}_{4}$ molar ratio of 61 . Point A: $\mathrm{H}_{2} \mathrm{O}$ switched off; Point $\mathrm{B}: \mathrm{H}_{2} \mathrm{O}$ reintroduced; Point $\mathrm{C}$ : $\mathrm{O}_{2}$ added with an $\mathrm{He} / \mathrm{O}_{2}$ molar ratio of 19 ; Point D: $\mathrm{O}_{2}$ switched off.

firms their catalytic role. Importantly, the activity data in Figure 2 were collected after $7 \mathrm{~h}$ on stream, whereas almost complete loss of destructive-adsorption activity was observed after $5.5 \mathrm{~h}$ and $40 \mathrm{~min}$ for pure and alumina-supported lanthanide oxide materials, respectively. Figure 3 further illustrates the essential role of steam for the catalytic performance of the $10 \mathrm{wt} \% \mathrm{La}_{2} \mathrm{O}_{3} / \mathrm{Al}_{2} \mathrm{O}_{3}$ catalyst. Under our standard reaction conditions $\left(\mathrm{H}_{2} \mathrm{O} / \mathrm{CCl}_{4}\right.$ molar ratio of 61$)$, complete conversion was maintained at $350^{\circ} \mathrm{C}$ for more than $3 \mathrm{~d}$. When the steam supply was switched off (point A in Figure 3), the conversion gradually declined from 100 to $22 \%$ over $12 \mathrm{~h}$. When steam was added to the system again (point $\mathrm{B}$ ), $100 \% \mathrm{CCl}_{4}$ conversion was quickly regained and maintained for more than three days. The difference in the system response on steam shut off and addition is notable. Specifically, steam reintroduction results in an almost immediate restoration of the catalytic destruction rate, whereas without steam, the activity decreases over a longer time period. This phenomenon is even more pronounced for unsupported lanthanide oxide catalysts. ${ }^{[16]}$ These results indicate that surface dechlorination by steam is a relatively fast process compared to bulk diffusion of chlorine and oxygen atoms.

In addition to experiments with steam, the effect of oxygen addition was investigated. When $\mathrm{O}_{2}\left(\mathrm{He} / \mathrm{O}_{2}\right.$ ratio of 19) was co-fed with steam (point $\mathrm{C}$ in Figure 3), the $\mathrm{CCl}_{4}$ conversion dropped from 100 to $60 \%$. This result suggests that the active site for the destructive adsorption is lattice rather than adsorbed oxygen, and that gas-phase $\mathrm{CCl}_{4}$ and $\mathrm{O}_{2}$ compete for surface sites. This result also has a practical implication, since gas streams of commercial plants from which removal of CHCs is required may contain some oxygen: a somewhat lower, but still stable and high catalytic activity could be achieved and maintained in the presence of oxygen. Switching the oxygen supply off (point D in Figure 3) restored complete conversion of $\mathrm{CCl}_{4}$, and this activity could be maintained for more than four days.

Weiss et al. have already reported on the catalytic hydrolysis of $\mathrm{CCl}_{4}$ to $\mathrm{HCl}$ and $\mathrm{CO}_{2}$ in the presence of steam over unsupported $\mathrm{MgO}$ at $500^{\circ} \mathrm{C},{ }^{[17 \mathrm{a}]}$ whereas Fenelonov et al. reported the dehydrochlorination activity of $\mathrm{MgO}$ towards 1 chlorobutane between 200 and $350^{\circ} \mathrm{C}^{[176]}$ Our results indicate that alkaline-earth metals are indeed active in dechlorination reactions, but the conversions are lower than those of lanthanide oxide-based catalysts (Figure 4). Under identical

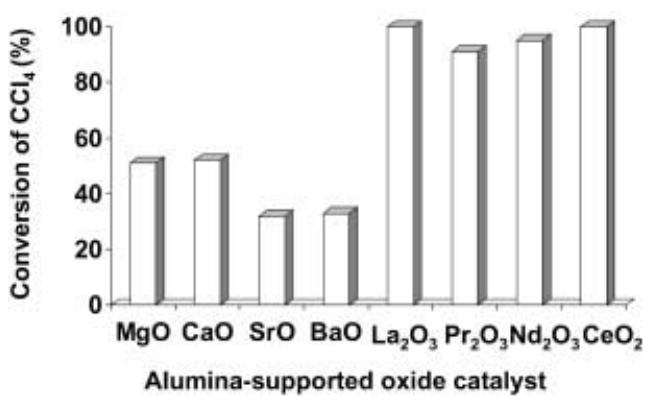

Figure 4. $\mathrm{CCl}_{4}$ conversion in the presence of steam $\left(\mathrm{H}_{2} \mathrm{O} / \mathrm{CCl}_{4}\right.$ feed molar ratio of 61 ) at $350^{\circ} \mathrm{C}$ after $7 \mathrm{~h}$ on stream over $10 \mathrm{wt} \%$ alumina-supported metal oxides.

reaction conditions the $\mathrm{CCl}_{4}$ conversions at $350^{\circ} \mathrm{C}$ for $10 \mathrm{wt} \%$ alumina-supported $\mathrm{MgO}, \mathrm{CaO}, \mathrm{SrO}$, and $\mathrm{BaO}$ catalysts are $51,52,32$, and $33 \%$, respectively. The catalytic activities of the other lanthanide-oxide-based catalysts are included in Figure 4 for comparison. Like $\mathrm{La}_{2} \mathrm{O}_{3} 10 \mathrm{wt} \%$ alumina-supported $\mathrm{CeO}_{2}, \mathrm{Pr}_{2} \mathrm{O}_{3}$ and $\mathrm{Nd}_{2} \mathrm{O}_{3}$ all have higher activities than the tested alkaline-earth metals.

Raman spectroscopic studies: In situ Raman spectra recorded during $\mathrm{CCl}_{4}$ decomposition in the presence of steam [Eq. (3)] at an $\mathrm{H}_{2} \mathrm{O} / \mathrm{CCl}_{4}$ molar ratio of 61 are shown in Figure $5 \mathrm{~A}$. The spectrum of the pure $\mathrm{La}_{2} \mathrm{O}_{3}$ starting material is dominated by three bands at 106, 190, and $408 \mathrm{~cm}^{-1}$, which are close to those reported in the literature and calculated by us for model catalysts (Table 1). ${ }^{[18-21]}$ After $16 \mathrm{~h}$ on

Table 1. Experimental and theoretically calculated (in parentheses) Raman shifts for $\mathrm{La}_{2} \mathrm{O}_{3}, \mathrm{LaOCl}$ and $\mathrm{LaCl}_{3}$.

\begin{tabular}{lll}
\hline $\begin{array}{l}\text { Catalyst mate- } \\
\text { rial }\end{array}$ & Raman shift $\left[\mathrm{cm}^{-1}\right]$ & Ref. \\
\hline $\mathrm{La}_{2} \mathrm{O}_{3}$ & $107(102), 195(211), 410(400)$ & $-{ }^{[18]}$ \\
$\mathrm{LaOCl}$ & $125(125), 188(176), 215(206), 335(334), 440$ & $-{ }^{[19,20]}$ \\
& $(444)$ & \\
$\mathrm{LaCl}_{3}$ & $108(112), 180(184), 186(187), 212(191), 219$ & - \\
& $(195)$ & {$[19,20,21]$}
\end{tabular}


A)

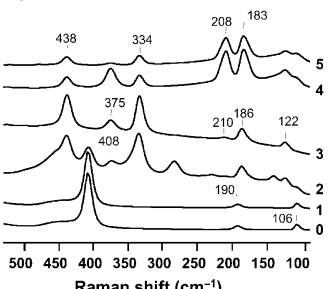

B)

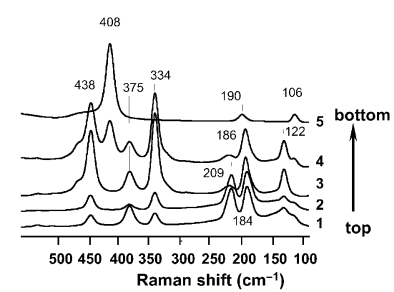

Figure 5. Raman spectra of $\mathrm{La}_{2} \mathrm{O}_{3}$ during the reaction of $\mathrm{CCl}_{4}$ with $\mathrm{H}_{2} \mathrm{O}$ $\left(\mathrm{H}_{2} \mathrm{O} / \mathrm{CCl}_{4}\right.$ molar ratio of 61$)$ at $350{ }^{\circ} \mathrm{C}$ : A) after 0) 0,1$\left.\left.) 8,2\right) 16,3\right) 24$, 4) 36 , and 5) $48 \mathrm{~h}$ on stream; and B) reactor "mapping" from 1 (top) to 5 (bottom) after $36 \mathrm{~h}$ on stream.

by Raman spectroscopy after $36 \mathrm{~h}$ (Figure $5 \mathrm{~B}$ ). The in situ spectra indicate that almost pure $\mathrm{LaCl}_{3}$ was formed at the top of the reactor $\left(\mathrm{CCl}_{4}\right.$ feed inlet). However, at the bottom, the catalyst remained as $\mathrm{La}_{2} \mathrm{O}_{3}$, and in the middle section, the presence of all three La phases was detected.

In the second series of experiments, the effect of the $\mathrm{H}_{2} \mathrm{O}$ / $\mathrm{CCl}_{4}$ molar ratio was investigated with in situ Raman spectroscopy by varying this ratio from 360 (Figure 6A) to 10 (Figure 6B). The spectra in Figure 6A show that the high steam concentration practically preserved the sample in its original $\mathrm{La}_{2} \mathrm{O}_{3}$ form after $16 \mathrm{~h}$ on stream. Complete $\mathrm{CCl}_{4}$ conversion was observed under these conditions. In contrast, stream, the peaks due to $\mathrm{La}_{2} \mathrm{O}_{3}$ disappear, and new Raman bands at 122, 186, 210, 334, 375, and $438 \mathrm{~cm}^{-1}$ become apparent. These Raman bands, except for the peak at $375 \mathrm{~cm}^{-1}$, are attributed to $\mathrm{LaOCl}$. To elucidate the nature of the Raman band at $375 \mathrm{~cm}^{-1}$, different laser excitations were used. In the Raman spectra obtained with 785 and $1064 \mathrm{~nm}$ laser excitation, this band was not observed. Therefore, it can be explained by the luminescence effect mentioned by Bowie et al. ${ }^{[22,23]}$ Thus, an almost complete transformation of $\mathrm{La}_{2} \mathrm{O}_{3}$ into $\mathrm{LaOCl}$ occurred [Eq. (4)].

$\mathrm{La}_{2} \mathrm{O}_{3}+0.5 \mathrm{CCl}_{4} \rightarrow 2 \mathrm{LaOCl}+0.5 \mathrm{CO}_{2}$

Complete $\mathrm{CCl}_{4}$ conversion was still maintained after $24 \mathrm{~h}$, by which time the Raman spectrum was dominated by features of $\mathrm{LaOCl}$. This result suggests that, besides $\mathrm{La}_{2} \mathrm{O}_{3}$, $\mathrm{LaOCl}$ is also an active phase. The relative activity of these two phases could not be determined in our current experiments and will be addressed in the future. ${ }^{[24]}$ However, both phases should have a common active site that enables initial breaking of the $\mathrm{C}-\mathrm{Cl}$ bond. After $36 \mathrm{~h}$ on stream, new bands that became visible at 183 and $208 \mathrm{~cm}^{-1}$ indicated the onset of further transformation into $\mathrm{LaCl}_{3}$ [Eq. (5)].

$2 \mathrm{LaOCl}+\mathrm{CCl}_{4} \rightarrow 2 \mathrm{LaCl}_{3}+\mathrm{CO}_{2}$

After $48 \mathrm{~h}$, both phases were still clearly present, but the intensity of $\mathrm{LaOCl}$ bands decreased, while those of $\mathrm{LaCl}_{3}$ increased. These results show that the transformation of $\mathrm{La}_{2} \mathrm{O}_{3}$ into $\mathrm{LaOCl}$ [Eq. (4)] in the presence of steam is faster than the transformation of $\mathrm{LaOCl}$ into $\mathrm{LaCl}_{3}$ [Eq. (5)]. However, the presence of steam slows the chlorination process by concurrently regenerating the metal oxide from $\mathrm{LaCl}_{3}$ [Eq. (2)] and $\mathrm{LaOCl}$, as evidenced by separate steam dechlorination experiments. To confirm the progressive chlorination of $\mathrm{La}_{2} \mathrm{O}_{3}$, the catalyst bed was "mapped" the low $\mathrm{H}_{2} \mathrm{O} / \mathrm{CCl}_{4}$ ratio of 10 led to fast chlorination of the solid to $\mathrm{LaOCl}$ and further to $\mathrm{LaCl}_{3}$ (Figure 6B) and consequently to an almost complete loss of $\mathrm{CCl}_{4}$ decomposition activity. This result provides further evidence for the critical role of lattice oxygen in $\mathrm{CCl}_{4}$ decomposition and the catalytic inactivity of the $\mathrm{LaCl}_{3}$ phase. The gradual bulk transformation of $\mathrm{La}_{2} \mathrm{O}_{3}$ into $\mathrm{LaOCl}$ and further into $\mathrm{LaCl}_{3}$ was also confirmed by XRD for different $\mathrm{H}_{2} \mathrm{O} / \mathrm{CCl}_{4}$ molar ratios and reaction times. Bulk transformation studies with Raman spectroscopy for our alumina-supported lanthanide oxide catalysts were hindered by strong fluorescence. ${ }^{[25]}$

IR spectroscopic studies: In situ IR spectra of the gas phase were recorded to investigate the possible formation of gaseous intermediates. Figure 7 shows spectra recorded during $\mathrm{CCl}_{4}$ conversion in the presence of steam over $\mathrm{La}_{2} \mathrm{O}_{3}$ at $350^{\circ} \mathrm{C}$ after $1,2,4$, and $8 \mathrm{~h}$ on stream. Peaks were observed at 2890, 2348, 2143, and $1827 \mathrm{~cm}^{-1}$ and assigned to $\mathrm{HCl}$, $\mathrm{CO}_{2}, \mathrm{CO}$, and $\mathrm{COCl}_{2}$, respectively. ${ }^{[26]} \mathrm{We}$ attribute the small concentrations of $\mathrm{CO}$ to a side reaction with formation of chlorine [Eq. (6)].

$\mathrm{CCl}_{4}+\mathrm{H}_{2} \mathrm{O} \rightarrow \mathrm{CO}+2 \mathrm{HCl}+\mathrm{Cl}_{2}$

$\mathrm{Cl}_{2}$ is likely to react with the catalyst surface with the formation of $\mathrm{O}_{2}$, and therefore Equation (6) can also be written as Equation (7). 


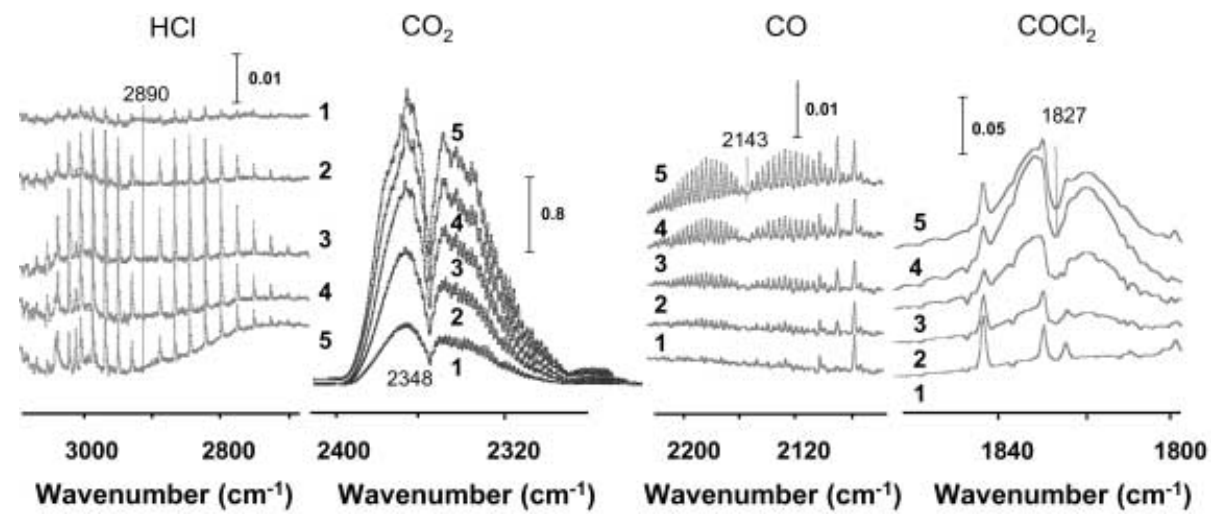

Figure 7. IR spectra of the gas phase in the in situ reactor cell after 1) $0.5,2) 1,3) 2$, 4) 4, and 5) $8 \mathrm{~h}$ on stream for the reaction of $\mathrm{CCl}_{4}+\mathrm{H}_{2} \mathrm{O}\left(\mathrm{H}_{2} \mathrm{O} / \mathrm{CCl}_{4}\right.$ molar ratio of 61$)$ over $\mathrm{La}_{2} \mathrm{O}_{3}$ at $350^{\circ} \mathrm{C}$.

$2 \mathrm{CCl}_{4}+4 \mathrm{H}_{2} \mathrm{O} \rightarrow 2 \mathrm{CO}+8 \mathrm{HCl}+\mathrm{O}_{2}$

We propose that $\mathrm{COCl}_{2}$ is a reaction intermediate. The mechanism of its formation and decomposition is discussed below. Additional IR measurements indicate that the $\mathrm{COCl}_{2}$ concentration increases with increasing temperature.

X-ray photoelectron spectroscopy studies: X-ray photoelectron spectroscopy (XPS) was used to monitor the extent of surface chlorination of $\mathrm{La}_{2} \mathrm{O}_{3}$ with time on stream. Relative changes in intensity of the O1s (ca. $531 \mathrm{eV}$ ), Cl2s (ca. $269 \mathrm{eV}$ ), and $\mathrm{La} 4 \mathrm{~s}$ (ca. $275 \mathrm{eV}$ ) peaks for treatment at an $\mathrm{H}_{2} \mathrm{O} / \mathrm{CCl}_{4}$ molar ratio of 61 at $350^{\circ} \mathrm{C}$ are summarized in Table 2. For comparison, the XPS peak positions for $\mathrm{La}_{2} \mathrm{O}_{3}$, catalyst chlorination is not only a surface process, but also a solid-state reaction in which oxygen diffuses from the bulk to the surface to undergo $\mathrm{O} / \mathrm{Cl}$ exchange. This conclusion is in agreement with facile anion diffusion observed by NMR experiments on lanthanum fluorides and hydroxide fluorides. ${ }^{[28]}$ Finally, we note that increasing the feed $\mathrm{H}_{2} \mathrm{O} / \mathrm{CCl}_{4}$ molar ratio increased the $\mathrm{O} / \mathrm{La}$ and reduced the $\mathrm{Cl} / \mathrm{La}$ peak ratios. Specifically, changing the $\mathrm{H}_{2} \mathrm{O} / \mathrm{CCl}_{4}$ molar ratio from 10 to 61 and then to 360 changed the $\mathrm{Cl} / \mathrm{La}$ peak ratio, respectively, from 1.13 to 0.91 and then to 0.23 for a $16 \mathrm{~h}$ treatment at $350{ }^{\circ} \mathrm{C}$. This observation further confirms the progressive transformation of $\mathrm{La}_{2} \mathrm{O}_{3}$ into $\mathrm{LaCl}_{3}$ in the absence of sufficient steam pressure for regenerating the catalyst surface.
Table 2. Binding energies of La4s, Cl2s, and O1s XPS peaks and relative peak ratios for pure $\mathrm{La}_{2} \mathrm{O}_{3}, \mathrm{LaOCl}$, $\mathrm{LaCl}_{3}$, and a $\mathrm{La}_{2} \mathrm{O}_{3}$ sample treated with $\mathrm{CCl}_{4}$ and $\mathrm{H}_{2} \mathrm{O}$ at $350^{\circ} \mathrm{C}$ as a function of time on stream for an $\mathrm{H}_{2} \mathrm{O}$ / $\mathrm{CCl}_{4}$ ratio of 61

\begin{tabular}{|c|c|c|c|c|c|c|}
\hline \multirow[t]{2}{*}{ Catalyst material } & \multirow{2}{*}{$\begin{array}{l}\text { Relative amounts of } \mathrm{La}_{2} \mathrm{O}_{3}, \mathrm{LaOCl} \text {, } \\
\text { and } \\
\mathrm{LaCl}_{3} \text { at the catalyst surface }\end{array}$} & \multicolumn{3}{|c|}{$\begin{array}{c}\text { Binding energies } \\
(\mathrm{eV})\end{array}$} & \multicolumn{2}{|c|}{ XPS peak ratios } \\
\hline & & $\mathrm{La} 4 \mathrm{~s}$ & $\mathrm{Cl} 2 \mathrm{~s}$ & O1s & $\begin{array}{l}\mathrm{O} 1 \mathrm{~s} / \\
\mathrm{La} 4 \mathrm{~s}\end{array}$ & $\begin{array}{l}\mathrm{Cl} 2 \mathrm{~s} / \\
\mathrm{La} 4 \mathrm{~s}\end{array}$ \\
\hline $\mathrm{La}_{2} \mathrm{O}_{3}$ & $100 \% \mathrm{La}_{2} \mathrm{O}_{3}$ & 275.1 & $\mathrm{na}^{[\mathrm{b}]}$ & 531.4 & 0.32 & na \\
\hline $\mathrm{LaOCl}$ & $100 \% \mathrm{LaOCl}$ & 275.2 & 269.1 & 531.0 & 0.18 & 5.5 \\
\hline $\mathrm{LaCl}_{3}$ & $100 \% \mathrm{LaCl}_{3}$ & 275.4 & 269.4 & na & 0.09 & 7 \\
\hline $\mathrm{La}_{2} \mathrm{O}_{3}$ after $2 \mathrm{~h}$ of reaction & $100 \% \mathrm{La}_{2} \mathrm{O}_{3}$ & 275.1 & $\mathrm{nd}^{[\mathrm{c}]}$ & 531.4 & 0.31 & 0 \\
\hline $\mathrm{La}_{2} \mathrm{O}_{3}$ after $8 \mathrm{~h}$ of reaction & $100 \% \mathrm{La}_{2} \mathrm{O}_{3}$ & 275.2 & nd & 531.4 & 0.31 & 0 \\
\hline $\begin{array}{l}\mathrm{La}_{2} \mathrm{O}_{3} \text { after } 16 \mathrm{~h} \text { of reac- } \\
\text { tion }\end{array}$ & $64 \% \mathrm{La}_{2} \mathrm{O}_{3}+36 \% \mathrm{LaOCl}$ & 275.2 & 269.1 & 531.3 & 0.27 & 0.91 \\
\hline $\begin{array}{l}\mathrm{La}_{2} \mathrm{O}_{3} \text { after } 24 \mathrm{~h} \text { of reac- } \\
\text { tion }\end{array}$ & $8 \% \mathrm{La}_{2} \mathrm{O}_{3}+92 \% \mathrm{LaOCl}$ & 275.2 & 269.2 & 531.2 & 0.19 & 7.5 \\
\hline $\begin{array}{l}\mathrm{La}_{2} \mathrm{O}_{3} \text { after } 36 \text { h of reac- } \\
\text { tion }\end{array}$ & $67 \% \mathrm{LaOCl}+33 \% \mathrm{LaCl}_{3}$ & 275.3 & 269.3 & 531.1 & 0.15 & 4.4 \\
\hline
\end{tabular}

[a] The values are estimates of the individual contributions of $\mathrm{La}_{2} \mathrm{O}_{3}, \mathrm{LaOCl}$ and $\mathrm{LaCl}_{3}$ to the overall XPS spectrum based on the measured XPS O1s/La4s and $\mathrm{Cl} 2 \mathrm{~s} / \mathrm{La} 4 \mathrm{~s}$ peak ratios of the catalyst materials and those of the reference compounds. [b] na = not applicable. [c] nd $=$ not detected.

$\mathrm{LaOCl}$, and $\mathrm{LaCl}_{3}$ as reference compounds are also included. ${ }^{[27]}$ The results in Table 2 indicate that after 2 and $8 \mathrm{~h}$ on stream the catalyst surface remained almost entirely in its original $\mathrm{La}_{2} \mathrm{O}_{3}$ form. After $16 \mathrm{~h}$, the catalyst surface became a mixture of $\mathrm{La}_{2} \mathrm{O}_{3}$ and $\mathrm{LaOCl}$, after $24 \mathrm{~h}$ it had transformed into mostly $\mathrm{LaOCl}$ and after $36 \mathrm{~h}$ into a mixture of $\mathrm{LaOCl}$
DFT calculations: The experimental observations that 1 ) destructive adsorption of $\mathrm{CCl}_{4}$ on $\mathrm{La}_{2} \mathrm{O}_{3}$ occurs in the absence of gas-phase $\mathrm{O}_{2}$, and 2) that the reaction rate of $\mathrm{CCl}_{4}$ destruction in the presence of steam over $\mathrm{La}_{2} \mathrm{O}_{3}$ materials decreases when $\mathrm{O}_{2}$ is introduced in the inlet stream (Figure 3) suggest that the reaction occurs over a terminal lattice oxygen site. The other possible reaction mechanisms for hydrocarbon activation, which have been proposed, for example, for methane coupling over La-based catalysts, do not seem to apply in this case. ${ }^{[1,29]}$ Specifically, hydrocarbon activation is not likely to proceed over adsorbed oxygen because the presence of oxygen in the feed is not required, and, furthermore, it actually reduces the reaction rate. In addition, as the reaction starts at temperatures below $250^{\circ} \mathrm{C}$, the formation of gas-phase radicals should be limited, and, consequently, a free-radical mechanism is unlikely to play a significant role. Another possible mecha- 
nism, a reduction/oxidation cycle for the catalyst metal, similar to the $\mathrm{CuCl} / \mathrm{CuCl}_{2}$ transition, is unlikely because of the large ionization potential for the $\mathrm{La}^{0} / \mathrm{La}^{3+}$ transition: $\mathrm{La}^{3+}$ is usually regarded as being in a catalytically irreducible state. ${ }^{[30]}$ Therefore, only a reaction mechanism with lattice oxygen as an active site is considered here.

The results of our DFT calculations indicate that the destructive adsorption of $\mathrm{CCl}_{4}$ over $\mathrm{La}_{2} \mathrm{O}_{3}$ occurs by stepwise $\mathrm{Cl}$ donation from the $\mathrm{CHC}$ to the surface. As illustrated in Figure 8, when $\mathrm{CCl}_{4}$ approaches the surface, one of the $\mathrm{Cl}$
A)
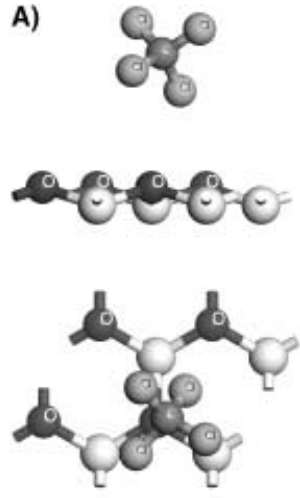

$\mathrm{CCl}_{4}$

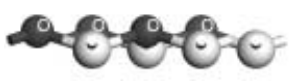

B)
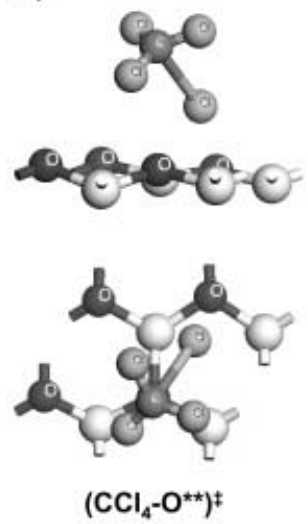

C)
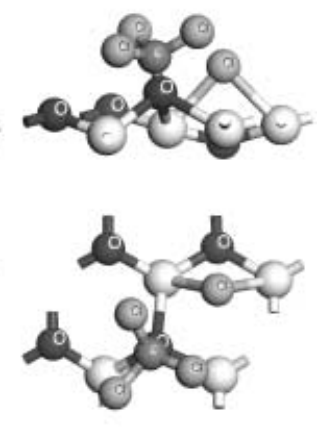

$\mathrm{CCl}_{3} \mathrm{O}^{*}+\mathrm{Cl}^{*}$
Figure 8. Mechanism of $\mathrm{CCl}_{4}$ decomposition over $\mathrm{La}_{2} \mathrm{O}_{3}(001)$. Side and top views of a simplified representation with top two catalyst layers only. A) $\mathrm{CCl}_{4}$ approaching the surface; B) transition state for dissociative adsorption; $\mathrm{C}$ ) adsorbed $\mathrm{CCl}_{3}$ and $\mathrm{Cl}$.

atoms is activated over a surface acid site associated with La. In the identified transition state (Figure $8 \mathrm{~B}$ ), the activated chlorine atom receives a partial negative charge $\left(\mathrm{Cl}^{\delta-}\right)$ and the $\mathrm{C}-\mathrm{Cl}$ distance for the activated bond increases from the gas-phase value of 1.8 to $3.4 \AA$. The rest of the $\mathrm{CHC}$ fragment becomes $\left(\mathrm{CCl}_{3}\right)^{\delta+}$, and the other $\mathrm{C}-\mathrm{Cl}$ distances decrease to $1.7 \AA$. This initial step can be described as electrophilic elimination over an acid site. On adsorption, the $\mathrm{CCl}_{3}$ cation is stabilized on a terminal lattice oxygen site by forming $\mathrm{O}-\mathrm{CCl}_{3}$ species with a $\mathrm{C}-\mathrm{Cl}$ bond length of $1.9 \AA$ (Figure $8 \mathrm{C}$ ). In essence, one of the $\mathrm{La}^{-} \mathrm{O}-\mathrm{La}$ bonds breaks, and $\mathrm{La}-\mathrm{Cl}$ and $\mathrm{La}-\mathrm{O}-\mathrm{CCl}_{3}$ bonds are formed. The surface $\mathrm{Cl}$ atom bridges two La atoms with a bond length of $2.9 \AA$. The terminal lattice $\mathrm{O}$ atom bonded to $\mathrm{C}$ is lifted up from its original position, whereby the $\mathrm{La}-\mathrm{O}$ bond length increases from 2.4 to $2.6 \AA$. The initial $\mathrm{CCl}_{4}$ decomposition step in Figure 8 is predicted to be exothermic with a reaction energy of $-192 \mathrm{~kJ} \mathrm{~mol}^{-1}$ and an activation barrier of $E_{\mathrm{a}}=$ $147 \mathrm{~kJ} \mathrm{~mol}^{-1}$, as illustrated in the energy diagram of Figure 9. In addition to the configuration of $\mathrm{O}-\mathrm{CCl}_{3}$ and $\mathrm{Cl}$ in Figure $8 \mathrm{C}$, several other arrangements were considered, including those with the surface $\mathrm{Cl}$ above a La atom or above a second-layer $\mathrm{O}$ atom. All considered arrangements had similar energies, within $10 \mathrm{~kJ} \mathrm{~mol}^{-1}$. We note that the absolute accuracy of DFT calculations is usually insufficient for predicting experimental kinetics. However, the calculated values can be useful as initial estimates in kinetic model-

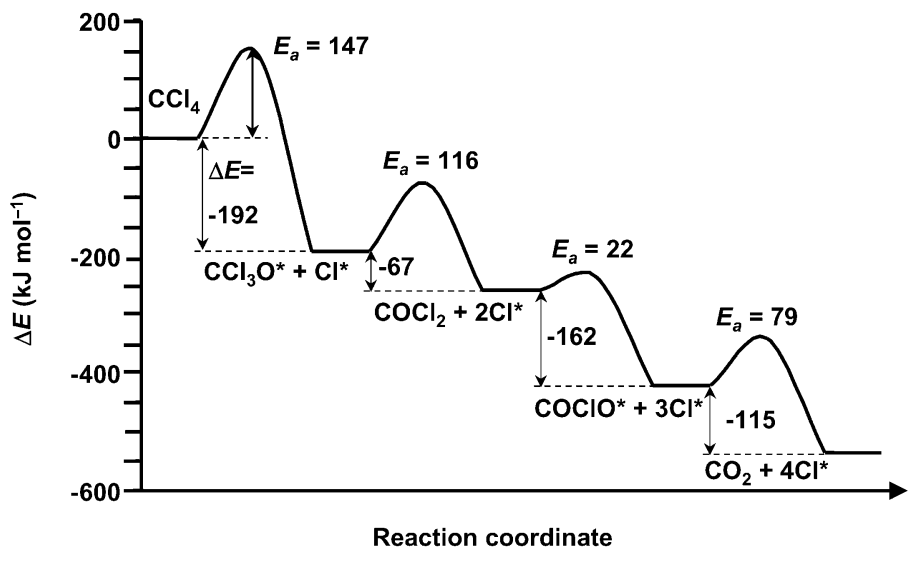

Figure 9. Energy diagram for $\mathrm{CCl}_{4}$ decomposition on $\mathrm{La}_{2} \mathrm{O}_{3}(001)$. Reference energy is defined as $\mathrm{CCl}_{4}+2 \mathrm{H}_{2} \mathrm{O}+\mathrm{La}_{2} \mathrm{O}_{3}$.

ing and as a basis for comparing the relative significance of the elementary steps in the reaction mechanism.

The $\mathrm{O}-\mathrm{CCl}_{3}$ surface species can decompose by donating a $\mathrm{Cl}$ atom to the surface and abstracting the bonding lattice oxygen atom. This reaction can occur in two energetically equivalent scenarios: in one step by concerted $\mathrm{Cl}$ donation and $\mathrm{O}-\mathrm{CCl}_{2}$ desorption, or in two steps, in which $\mathrm{Cl}$ is donated first. The latter scenario is analogous to the well-studied mechanism of $\mathrm{CCl}_{2}$ formation by liquid-phase $\mathrm{CHCl}_{3}$ hydrolysis. ${ }^{[31]}$ The $\mathrm{O}-\mathrm{CCl}_{3}$ decomposition is similar to the previously described step illustrated in Figure 9 in the sense that $\mathrm{La}-\mathrm{O}$ and $\mathrm{C}-\mathrm{Cl}$ bonds are broken and, instead, $\mathrm{La}-\mathrm{Cl}$ and $\mathrm{C}-\mathrm{O}$ bonds are formed. The overall stoichiometry for the two elementary steps corresponds to an exchange of two $\mathrm{Cl}$ atoms from the $\mathrm{CHC}$ for one lattice $\mathrm{O}$ atom with the formation of phosgene as gas-phase intermediate [Eq. (8)].

$\mathrm{La}_{2} \mathrm{O}_{3}+\mathrm{CCl}_{4} \rightarrow 2 \mathrm{LaOCl}+\mathrm{COCl}_{2}$

As shown in Figure 7, formation of the phosgene intermediate was confirmed by IR measurements. The second step is less exothermic $\left(\Delta E=-67 \mathrm{~kJ} \mathrm{~mol}^{-1}\right)$ and more facile $\left(E_{\mathrm{a}}=116 \mathrm{~kJ} \mathrm{~mol}^{-1}\right)$ than the first (Figure 9). Similarly to $\mathrm{CCl}_{4}$, the $\mathrm{COCl}_{2}$ intermediate can be adsorbed on a terminal lattice oxygen atom to form $\mathrm{O}-\mathrm{COCl}$ by splitting of a $\mathrm{Cl}$ atom. Phosgene is predicted to be very reactive, the activation energy for its destructive adsorption being $22 \mathrm{~kJ} \mathrm{~mol}^{-1}$, which compares with $147 \mathrm{~kJ} \mathrm{~mol}^{-1}$ for $\mathrm{CCl}_{4}$ (Figure 9). The donation of the last $\mathrm{Cl}$ atom from $\mathrm{O}-\mathrm{COCl}$ to the surface leads to the formation of gas-phase $\mathrm{CO}_{2}$. Like all other destructive adsorption steps, this step is predicted to be exothermic, as shown in Figure 9. The calculated barrier for gas-phase phosgene hydrolysis is $159 \mathrm{~kJ} \mathrm{~mol}^{-1}$, which is substantially higher than $22 \mathrm{~kJ} \mathrm{~mol}^{-1}$ predicted for $\mathrm{COCl}_{2}$ decomposition on $\mathrm{La}_{2} \mathrm{O}_{3}$. Therefore, the calculations indicate that $\mathrm{COCl}_{2}$ decomposition occurs primarily catalytically.

Based on the analysis of all reaction barriers in the energy diagram of Figure 9, the first reaction step, splitting off the first chlorine atom, is predicted to be the rate-determining step in destructive adsorption. Therefore, the decomposition of intermediate $\mathrm{COCl}_{2}$ can be treated as quasi-equi- 
librated. The equilibrium constant for $\mathrm{CO}_{2}$ formation from $\mathrm{COCl}_{2}$ is predicted to decrease with increasing temperature, because the reaction is exothermic. Therefore, larger quantities of gas-phase $\mathrm{COCl}_{2}$ are predicted at elevated temperatures. This prediction is in agreement with our IR experiments mentioned above.

After substitution of two $\mathrm{Cl}$ atoms for one lattice $\mathrm{O}$ atom on the $\mathrm{La}_{2} \mathrm{O}_{3}$ surface, the two $\mathrm{Cl}$ atoms do not appear to be restricted to the position of the original $\mathrm{O}$ atom. Calculations indicate that they can assume multiple surface configurations. The barrier for surface diffusion is estimated to be about $80 \mathrm{~kJ} \mathrm{~mol}^{-1}$. In addition, surface $\mathrm{Cl}$ can diffuse into the bulk, and this forces subsurface oxygen to migrate to the surface. Diffusion of surface $\mathrm{Cl}$ into the bulk is predicted to be endothermic by $68 \mathrm{~kJ} \mathrm{~mol}^{-1}$. The estimated activation energy for this reaction is $208 \mathrm{~kJ} \mathrm{~mol}^{-1}$, which is larger than that for any other considered reaction step. Therefore, for nonregenerative destruction of $\mathrm{CCl}_{4}$ (in the absence of steam, Figure 1), bulk $\mathrm{Cl}-\mathrm{O}$ diffusion is predicted to be the rate-determining step. The caveat for this prediction is that bulk chlorination changes the lattice constants of the material, for example, as in the case of the $\mathrm{La}_{2} \mathrm{O}_{3}$ to $\mathrm{LaOCl}$ transition. Our periodic-slab calculations, in contrast, assumed invariable lattice constants and therefore most likely overestimated the bulk diffusion barrier.

Our DFT calculations predict that all surface dechlorination steps are endothermic. These reactions can proceed by stepwise hydroxyl formation and subsequent dehydroxylation [Eqs. (9)-(11)]

$$
\begin{aligned}
& 2 \mathrm{Cl}^{*}+\mathrm{H}_{2} \mathrm{O} \rightarrow \mathrm{HCl}+\mathrm{OH}^{*}+\mathrm{Cl}^{*} \\
& \mathrm{Cl}^{*}+\mathrm{OH}^{*}+\mathrm{H}_{2} \mathrm{O} \rightarrow \mathrm{HCl}+2 \mathrm{OH}^{*} \\
& 2 \mathrm{OH}^{*} \rightarrow \mathrm{O}^{* *}+\mathrm{H}_{2} \mathrm{O}
\end{aligned}
$$

or by reaction of surface $\mathrm{Cl}$ and $\mathrm{OH}$ [Eq. (12) and (13)].

$$
\begin{aligned}
& 2 \mathrm{Cl}^{*}+\mathrm{H}_{2} \mathrm{O} \rightarrow \mathrm{HCl}+\mathrm{OH}^{*}+\mathrm{Cl}^{*} \\
& \mathrm{Cl}^{*}+\mathrm{OH}^{*} \rightarrow \mathrm{HCl}+\mathrm{O}^{* *}
\end{aligned}
$$

An energy diagram for the former mechanism is provided in Figure 10. We emphasize again that the energies estimated from our DFT calculations are useful for relative comparisons, that is, identification of trends, rather than for an analysis of the absolute values. The relative comparison of the calculated reaction barriers indicates that the two reaction pathways have similar energetics with an overall $\Delta E=$ $E_{\mathrm{a}}=180 \mathrm{~kJ} \mathrm{~mol}^{-1}$, and the reverse chlorination reactions are practically unactivated. The diagram in Figure 10 shows the energies for four reaction steps, corresponding to the removal of four surface $\mathrm{Cl}$ atoms formed on $\mathrm{CCl}_{4}$ decomposition.

Steps 1 and 2 are the same reactions as steps 3 and 4 but at a different surface $\mathrm{Cl}$ coverage. As can be seen from Figure 10, the extent of surface chlorination does not have a significant effect on the energetics of the steam-dechlorination steps. All activation and reaction energies differ by no more than $17 \mathrm{~kJ} \mathrm{~mol}^{-1}$. Similar $\mathrm{Cl}$ coverage calculations were performed for $\mathrm{CCl}_{4}$ and $\mathrm{COCl}_{2}$ decomposition: the

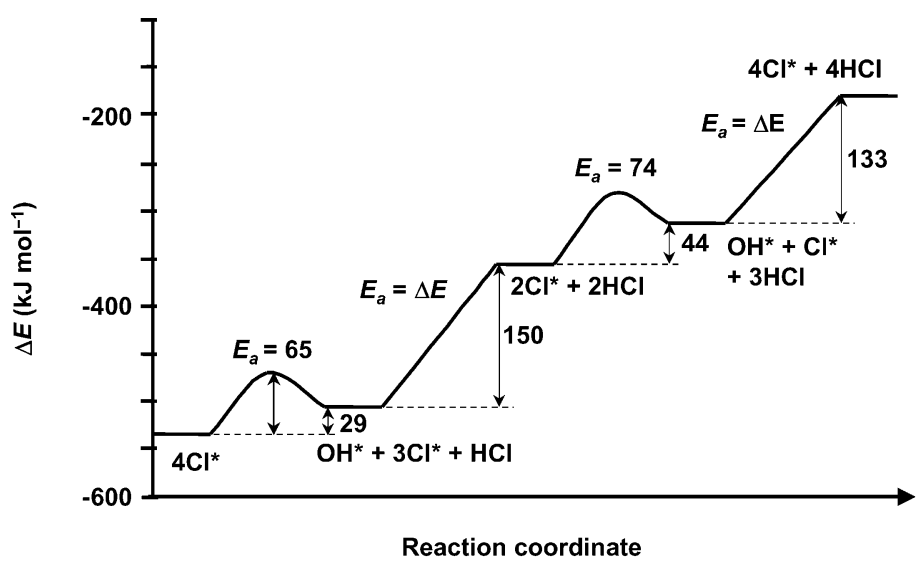

Figure 10. Energy diagram for removal of surface $\mathrm{Cl}$ with steam on $\mathrm{La}_{2} \mathrm{O}_{3}(001)$. The initial structure $4 \mathrm{Cl}^{*}$ is the same as the final structure in Figure 9. The reference state for Figures 9 and 10 is the same.

same transition states for destructive adsorption were evaluated on the clean $\mathrm{La}_{2} \mathrm{O}_{3}(001)$ surface and on a surface in which one terminal lattice $\mathrm{O}$ atom was substituted by two $\mathrm{Cl}$ atoms in the $2 \times 2$ unit cell. Similar to dechlorination, the activation energies for $\mathrm{CCl}_{4}$ destructive adsorption were found to be practically insensitive to the amount of surface Cl.

The reverse of the $\mathrm{O} / \mathrm{Cl}$ bulk diffusion discussed earlier occurs when $\mathrm{LaCl}_{3}$ is dechlorinated with steam (Figure 1). In this case, surface $\mathrm{O}$ atoms migrate into the bulk, and bulk $\mathrm{Cl}$ atoms onto the surface. The calculated barrier for this bulk diffusion is $140 \mathrm{~kJ} \mathrm{~mol}^{-1}$, which is lower than the overall barrier of about $180 \mathrm{~kJ} \mathrm{~mol}^{-1}$ predicted for the water surface reactions. Therefore, the dechlorination kinetics are predicted to be largely controlled by the surface reactions. If we assume that the same applies to other tested lanthanides, then the results in Figure 1 can be interpreted as an indication that the La-based material is a good catalyst candidate because its chlorinated surface can be easily regenerated.

With this mechanistic insight, the following explanation can be given for the results in Figure 3. Initially $\mathrm{CCl}_{4}$ was completely converted to $\mathrm{CO}_{2}$ by exchanging $4 \mathrm{Cl}$ for $2 \mathrm{O}$ atoms with the surface, and the surface was concurrently regenerated with $\mathrm{H}_{2} \mathrm{O}$ [Eq. (3)]. Under our standard testing conditions, the rates of chlorination and dechlorination were balanced for $\mathrm{La}_{2} \mathrm{O}_{3} / \mathrm{Al}_{2} \mathrm{O}_{3}$. In contrast, for pure $\mathrm{La}_{2} \mathrm{O}_{3}$ under the same conditions, the rate of surface chlorination was higher than the dechlorination rate. Combined with the bulk $\mathrm{Cl} / \mathrm{O}$ diffusion, this led to a gradual and continuous transformation of the initial $\mathrm{La}_{2} \mathrm{O}_{3}$ solid into $\mathrm{LaOCl}$ and, eventually, into $\mathrm{LaCl}_{3}$, as evidenced by Raman spectroscopy, XRD and XPS results (Figures 5 and 6, Table 2). A similar phenomenon was observed for the supported material on switching off the steam supply (point $\mathrm{A}$ in Figure 3). In this case, similarly to pure $\mathrm{La}_{2} \mathrm{O}_{3}$, chlorination of the solid was not counterbalanced by steam dechlorination. As a result, the observed $\mathrm{CCl}_{4}$ conversion declined with decreasing number of terminal lattice $\mathrm{O}$ sites, and the overall reaction rate was limited by diffusion of oxygen atoms from the bulk to the surface. 
The flux of oxygen atoms to the surface undoubtedly decreased with increasing extent of chlorination of the solid. Therefore, the apparent $\mathrm{CCl}_{4}$ conversion steadily declined with time on stream. These conclusions are supported by results obtained with a low $\mathrm{H}_{2} \mathrm{O} / \mathrm{CCl}_{4}$ ratio (Figure 6B). Reintroduction of steam dechlorinated (regenerated) the solid, and the initial activity was restored and maintained (point B in Figure 3). The dechlorination capability of steam was confirmed in separate experiments with $\mathrm{LaCl}_{3}$ (Figure 1). Additionally, the ability to run the reaction in a catalytic mode by sufficiently regenerating the surface was confirmed in an experiment with a large excess of $\mathrm{H}_{2} \mathrm{O}$ (Figure $6 \mathrm{~A}$ ). Gasphase oxygen is apparently not as affective as $\mathrm{H}_{2} \mathrm{O}$ for surface dechlorination. In addition, $\mathrm{O}_{2}$ may compete with $\mathrm{CCl}_{4}$ for surface adsorption sites. As a result, introduction of $\mathrm{O}_{2}$ into the reaction mixture reduced $\mathrm{CCl}_{4}$ conversion (point $\mathrm{C}$ in Figure 3). The elimination of oxygen from the feed (point D in Figure 3) restored the initial catalyst activity and stability.

\section{Conclusion}

The catalytic destruction of $\mathrm{CCl}_{4}$ in the presence of steam was investigated at $200-350^{\circ} \mathrm{C}$ over a series of lanthanide ( $\mathrm{La}, \mathrm{Ce}, \mathrm{Pr}$, and $\mathrm{Nd}$ ) and alkaline-earth metal $(\mathrm{Mg}, \mathrm{Ca}, \mathrm{Sr}$, and $\mathrm{Ba}$ ) oxide-based catalysts by kinetic experiments, various spectroscopic techniques and DFT calculations. This new catalytic chemistry was achieved by combining destructive adsorption of $\mathrm{CCl}_{4}$ on a basic oxide surface and concurrent dechlorination of the resulting partially chlorinated solid by steam. The following conclusions can be drawn from this work:

1) The rates of $\mathrm{CCl}_{4}$ decomposition and steam dechlorination could be balanced over lanthanide-oxide-based materials to create a catalytic cycle. Depending on the reaction conditions, especially the $\mathrm{H}_{2} \mathrm{O} / \mathrm{CCl}_{4}$ molar ratio, the catalytic material was found to transform dynamically from the metal oxide state to the metal oxide chloride or metal trichloride state due to bulk diffusion of oxygen and chlorine atoms. Both $\mathrm{La}_{2} \mathrm{O}_{3}$ and $\mathrm{LaOCl}$ are active materials in this reaction, whereas $\mathrm{LaCl}_{3}$ is catalytically inactive. However, the two active phases are probably part of a common catalytic cycle, and further work should be directed towards understanding the properties of the active site. Gas-phase oxygen in the feed stream decreases the reaction rate; this indicates that oxygen is in competition with the chlorinated hydrocarbon for the active site.

2) Destructive adsorption of $\mathrm{CCl}_{4}$ proceeds over a terminal lattice oxygen site with donation of a $\mathrm{Cl}$ atom from $\mathrm{CCl}_{4}$ to the catalyst surface. The splitting of this first $\mathrm{Cl}$ atom is predicted to be the rate-determining step. The resulting $\mathrm{O}-\mathrm{CCl}_{3}$ adsorbate can further decompose by donating another $\mathrm{Cl}$ atom to the surface and abstracting the bonding oxygen atom, thus generating gas-phase $\mathrm{COCl}_{2}$ as a reaction intermediate, which was observed experimentally.
3) The decomposition of the highly reactive $\mathrm{COCl}_{2}$ intermediate is predicted to proceed primarily catalytically rather than by gas-phase hydrolysis.

4) Surface dechlorination reactions of chlorinated lanthanide oxides with steam are endothermic and proceed either by stepwise hydroxyl formation and subsequent dehydroxylation or by reaction of surface $\mathrm{Cl}$ and $\mathrm{OH}$.

5) Mechanistic studies indicate that catalyst activity can be enhanced by increasing the number of terminal lattice oxygen sites, for example, by depositing the lanthanide oxide active phase onto a high surface area support. In agreement with this prediction, a supported catalyst obtained from a $10 \mathrm{wt} \% \mathrm{La}_{2} \mathrm{O}_{3} / \mathrm{Al}_{2} \mathrm{O}_{3}$ precursor exhibited the highest destruction rate: $0.289 \mathrm{~g} \mathrm{CCl}_{4} \mathrm{~h}^{-1} \mathrm{~g}^{-1}$ catalyst at $350{ }^{\circ} \mathrm{C}$, which is higher than values for any other reported catalyst system.

The elucidated details of the reaction mechanism should facilitate future theoretical studies for kinetic modeling, process optimization and catalyst development. For example, we are planning to identify theoretically and then confirm experimentally promoters that can be added for further improvement of the lanthanide oxide-based system.

\section{Experimental Section}

Catalyst preparation: The following alkaline earths and lanthanide oxides were studied: $\mathrm{MgO}$ (Aldrich, 99\%, $117 \mathrm{~m}^{2} \mathrm{~g}^{-1}$ ), $\mathrm{CaO}$ (Aldrich, 99.9\%, $7 \mathrm{~m}^{2} \mathrm{~g}^{-1}$ ), SrO (Aldrich, 99.9\%, $2 \mathrm{~m}^{2} \mathrm{~g}^{-1}$ ), BaO (Aldrich, 97\%, $0.25 \mathrm{~m}^{2} \mathrm{~g}^{-1}$ ), $\mathrm{La}_{2} \mathrm{O}_{3}$ (Acros, 99\%, $1 \mathrm{~m}^{2} \mathrm{~g}^{-1}$ ), $\mathrm{CeO}_{2}$ (Aldrich, 99,9\%, $0.25 \mathrm{~m}^{2} \mathrm{~g}^{-1}$ ), $\mathrm{Pr}_{2} \mathrm{O}_{3}$ (Alfa Aesar, 99.9\%, $3 \mathrm{~m}^{2} \mathrm{~g}^{-1}$ ), and $\mathrm{Nd}_{2} \mathrm{O}_{3}$ (Alfa Aesar, $99.9 \%, 3 \mathrm{~m}^{2} \mathrm{~g}^{-1}$ ). Alumina-supported (Condea, $220 \mathrm{~m}^{2} \mathrm{~g}^{-1}$ ) alkaline earth and lanthanide-oxide-based catalysts were prepared by incipient wet impregnation of aqueous metal acetates. The origin and purity of the corresponding metal acetate salts were as follows: Mg (Aldrich, 99\%), Ca (Avocado, 98\%), Sr (Avocado, 98\%), Ba (Aldrich, 99\%), La (Fluka, 97\%), Ce (Aldrich, 99,9\%), Pr (Aldrich, 99.9\%), and Nd (Aldrich, $99.9 \%$ ). After impregnation, samples were dried at $100^{\circ} \mathrm{C}$ for $1 \mathrm{~h}$. The impregnation was repeated until the desired metal oxide loading was obtained. All catalysts were granulated before testing and characterization, and the $0.25-0.50 \mathrm{~mm}$ fraction was used for testing. Dechlorination experiments in the presence of steam were performed with the following metal chlorides: $\mathrm{MgCl}_{2}$ (VEL, pro analyze), $\mathrm{CaCl}_{2}$ (Riedel-de-Haen, $99 \%$ ), $\mathrm{SrCl}_{2}$ (Acros, 99\%), $\mathrm{BaCl}_{2}$ (Aldrich, 99\%), $\mathrm{LaCl}_{3}$ (Aldrich, 99.999\%), $\mathrm{CeCl}_{3}$ (Fluka, 98.5\%), $\mathrm{PrCl}_{3}$ (Acros, $99.9 \%$ ), and $\mathrm{NdCl}_{3}$ (Alfa Aesar, 99.9\%).

Activity testing: Activity tests were performed in a fixed-bed reactor at atmospheric pressure. The reactor consisted of a quartz tube loaded successively with quartz wool, quartz beads, quartz wool, $1 \mathrm{~g}$ of catalyst, quartz wool, quartz beads and quartz wool. The reactor was placed in a furnace in such a way that the catalyst bed was positioned in the center of the furnace. Samples were pretreated in $10 \mathrm{~cm}^{3} \mathrm{~min}^{-1}$ (STP) $\mathrm{O}_{2}$ flow at $450{ }^{\circ} \mathrm{C}$ overnight. During the reaction, a helium flow at $8 \mathrm{~cm}^{3} \mathrm{~min}^{-1}$ (STP) was passed through a saturator filled with $\mathrm{CCl}_{4}$ (VEL, pro analyze) and maintained at $0{ }^{\circ} \mathrm{C}$ in an ice bath to preserve the same vapor pressure and consequently the same $\mathrm{CCl}_{4}$ concentration of $0.047 \mathrm{vol} \%$. The gas hourly space velocity (GHSV) was $800 \mathrm{~h}^{-1}$. The gas flows were measured and controlled by Bronkhorst mass flow controllers. Water was added to the reactor at the rate of $0.02 \mathrm{~cm}^{3} \mathrm{~min}^{-1}$ (STP) by means of a Methrom dosimeter and evaporated when in contact with the reactor walls and bed. The $\mathrm{H}_{2} \mathrm{O} / \mathrm{CCl}_{4}$ molar ratio was in most cases 61 , and thus an excess of steam was added to the reaction mixture. Water in the effluent stream was trapped with an impinger at room temperature. The remaining gases were analyzed with a gas chromatograph (HP 4890D with an FID detec- 
tor and methanator) using a packed Hayesep Q CP column (80100 mesh, $3 \mathrm{~m}$ ).

Catalyst characterization: Surface areas and pore volumes of the materials were determined by $\mathrm{N}_{2}$ sorption measurements with a Micromeritics Accelerated Surface Area and Porosimetry ASAP 2400 instrument. Surface areas were calculated by using the BET model with micro- and macropores described by the Horvath-Kawazoe and BJH models, respectively. The amount of chlorine in the solids after the dechlorination experiments with steam was determined by $\mathrm{Ag}$ titration in $\mathrm{aNO}_{3}$ solution according to the Volhardt method. Raman spectra were recorded with a Holoprobe Kaiser Optical RXN-532 or RXN-785 spectrometer equipped with a holographic notch filter, laser Raman excitation at 532 or $785 \mathrm{~nm}$ and a CCD camera. Some Raman spectra were also measured with a Perkin-Elmer 2000 FT-Raman spectrometer with laser Raman excitation at $1064 \mathrm{~nm}$. A special in situ Raman cell was used that could be heated in a stream of reagents at elevated temperatures. IR spectra were collected with a Nicolet 730 FT-IR spectrometer. A special in situ IR cell was designed in which a catalyst wafer was placed in a quartz cell equipped with $\mathrm{KBr}$ windows. X-ray diffraction measurements were performed with a Siemens D5000 diffractometer using a Ni-filtered $\mathrm{Cu}_{\mathrm{K} \alpha}$ source with a wavelength of $0.154 \mathrm{~nm}$. X-ray photoelectron spectra were measured with a Vacuum Generators system using a CLAM-2 hemispherical analyzer for electron detection. Nonmonochromatic Al X-ray radiation was used for generating the photoelectrons at an anode current of $20 \mathrm{~mA}$ and $10 \mathrm{keV}$. The pass energy of the analyzer was set at $50 \mathrm{eV}$. The survey scan was taken with a pass energy of $100 \mathrm{eV}$.

Theoretical calculations: Gradient-corrected periodic DFT calculations with $\mathrm{La}_{2} \mathrm{O}_{3}(001)$ model surfaces were performed to elucidate the reaction mechanism using the $\mathrm{DMol}^{3}$ code in Materials Studio 2.2 software by Accelrys Inc. Infinite slabs were constructed similarly to a recently proposed $\mathrm{La}_{2} \mathrm{O}_{3}$ model. ${ }^{[32]}$ The models were based on a $2 \times 2 \mathrm{La}$ unit cell with an overall thickness of 10 layers: $2 \times(\mathrm{O}, \mathrm{La}, \mathrm{O}, \mathrm{La}, \mathrm{O})$, as shown in Figure 11. The bottom seven slab layers were constrained during the cal-

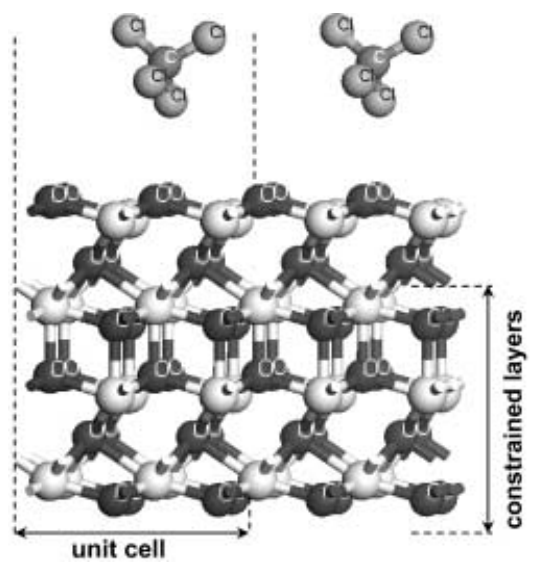

Figure 11. Periodic $\mathrm{La}_{2} \mathrm{O}_{3}(001)$ model surface based on a $2 \times 2$ 10-layer unit cell with $\mathrm{CCl}_{4}$ above the surface. A simplified representation with only the top two layers is shown in Figure 8.

culations, and the top three layers were optimized with an adsorbate to simulate surface relaxation on adsorption. All adsorption and surface reaction energies were calculated at $0 \mathrm{~K}$ without zero-point energy corrections. The vacuum spacing was $15 \AA$. The calculated equilibrium lattice constants closely matched accepted experimental values: $a=b=3.954$, $c=6.136 \AA$ (exptl: $a=b=3.939, c=6.136 \AA$ ). The calculations used the double numerical with polarization (DNP) basis set and the generalized gradient-corrected Perdew-Wang (GGA PW91) functional. The calculations were spin-nonpolarized. Tightly bound core electrons were represented with ultrasoft pseudopotentials. Reciprocal-space integration over the Brillouin zone was approximated by a sampling at $3 \times 3 \times 1 k$-points. Convergence with respect to the number of $k$-points was tested by in- creasing the mesh to $4 \times 4 \times 1$ for several representative structures. The real-space cutoff distance was $4.5 \AA$. The integration accuracy was set at 1000 grid points for each atom. The SCF tolerance was $10^{-5}$ Hartree. Octupole expansion was used in the maximum angular momentum function representation of the charge density. To facilitate convergence, the density mixing between consecutive iterations was set at 0.2 for the charge and 0.5 for the spin. In addition, direct inversion in an iterative subspace (DIIS) and thermal smearing of 0.002 Hartree were used.

\section{Acknowledgement}

This work was supported by the Instituut voor Aanmoediging van Innovatie door Wetenschap en Technologie in Vlaanderen (IWT-Vlaanderen; project ADV/990177). The authors acknowledge fruitful discussions with R. Schoonheydt (KULeuven), G. Mestl (Nanoscape), I. Langhans (CQ), K. Ooms (CQ), D. van Deynse (Tessenderlo Chemie), Y. Sergeant (Tessenderlo Chemie), and M. Belmans (Tessenderlo Chemie). XPS was performed by A. Mens and O. Gijzeman (Utrecht University). We thank the Dow Chemical Company for providing computational facilities to perform the DFT calculations. We also thank the following at Dow Chemicals for useful discussions: R. Gulotty, M. Jones, M. Olken, A. Schweizer, E. Stangland, R. Lee, and M. Tirtowidjojo. B.M.W. acknowledges the Dutch Science Foundation (NWO-CW) for a Van der Leeuw and VICI grant.

[1] P. Schmittinger, Chlorine, Principles and Industrial Practice, WileyVCH, Weinheim, 2000.

[2] D. Bose, S. Senkan, Combust. Sci. Technol. 1983, 35, 187; H. Valeirs, A. K. Gupta, S. Senkan, Combust. Sci. Technol. 1984, 36, 123.

[3] For example, M. Bonarowska, A. Malinowski, W. Juszczyk, Z. Karpinski, Appl. Catal. B 2001, 30, 187; G. C. Bond, N. Sadeghi, J. Appl. Chem. Biotechnol. 1975, 25, 241; E. Feijen-Jeurissen, J. J. Jorna, B. E. Nieuwenhuis, G. Sinquin, C. Petit, J. P. Hindermann, Catal. Today 1999, 54, 65; K. A. Frankel, B. W. Jang, J. J. Spivey, G. W. Robert, Appl. Catal. A 2001, 205, 263; S. Krishnamoorthy, J. A. Rivas, M. D. Amiridis, J. Catal. 2000, 193, 264; K. Intarajang, J. T. Richardson, Appl. Catal. B 1999, 22, 27.

[4] M. Wilde, K. Anders, Chem. Tech. 1994, 6, 316.

[5] K. J. Klabunde, J. Stark, O. Koper, C. Mohs, D. G. Park, S. Decker, Y. Yiang, I. Lagadic, D. Zhang, J. Phys. Chem. B 1998, 102, 3773.

[6] O. Koper, Y. X. Li, K. J. Klabunde, Chem. Mater. 1993, 5, 500; O. B. Koper, E. A. Wovchko, J. A. Glass, J. T. Yates, K. J. Klabunde, Langmuir 1995, 11, 2054; O. Koper, I. Lagadic, K. J. Klabunde, Chem. Mater. 1997, 9, 2481.

[7] P. D. Hooker, K. J. Klabunde, Environ. Sci. Technol. 1994, 28, 1243.

[8] B. M. Weckhuysen, G. Mestl, M. P. Rosynek, J. H. Lunsford, ACS Division of Environmental Chemistry Preprints of Extended Abstracts 1998, 38, 31; Chem. Eng. News, April 20 1998, 71.

[9] B. M. Weckhuysen, G. Mestl, M. P. Rosynek, T. R. Krawietz, J. F. Haw, J. H. Lunsford, J. Phys. Chem. B 1998, 102, 3773.

[10] B. M. Weckhuysen, M. P. Rosynek, J. H. Lunsford, Phys. Chem. Chem. Phys. 1999, 1, 3157.

[11] P. Van der Avert, B. M. Weckhuysen, Angew. Chem. 2002, 114, 4924; Angew. Chem. Int. Ed. 2002, 41, 4730; Chem. Eng. News, January 6, 2003, 24.

[12] B. Weckhuysen, R. Schoonheydt, P. Van der Avert, 03057318A1.

[13] Several attempts to perform similar experiments with pure $\mathrm{CeO}_{2}$ and $\mathrm{CeCl}_{3}$ at $300^{\circ} \mathrm{C}$ failed. This can be attributed to the redox change $\left(\mathrm{Ce}^{3+} / \mathrm{Ce}^{4+}\right)$ associated with the destructive adsorption of $\mathrm{CCl}_{4}$ over $\mathrm{CeO}_{2}$ and the steam dechlorination of $\mathrm{CeCl}_{3}$. Indeed, previous Raman spectroscopic experiments showed that $\mathrm{CeO}_{2}$ is transformed to $\mathrm{CeCl}_{3}$, but higher reaction temperatures are required than with $\mathrm{La}_{2} \mathrm{O}_{3} \cdot{ }^{[10]}$ This requirement for higher temperature was specific to pure $\mathrm{Ce}$ oxide samples and did not apply to those supported on alumina.

[14] To test this hypothesis, we also synthesized a series of $\mathrm{La}_{2} \mathrm{O}_{3}$ materials with surface areas between 20 and $55 \mathrm{~m}^{2} \mathrm{~g}^{-1}$. The surface areas of 
these materials, however, decrease during catalysis to values between 10 and $30 \mathrm{~m}^{2} \mathrm{~g}^{-1}$. A small effect of the surface area was noticeable, although a support material appeared to be essential for maintaining high degrees of lanthanide oxide dispersion.

[15] G. R. Lester, Catal. Today 1999, 53, 407.

[16] Similar observations were also made for the catalytic destruction of other $\mathrm{CHCs}$, such as $\mathrm{CH}_{2} \mathrm{Cl}_{2}$ and $\mathrm{CHCl}_{3}$.

[17] a) U. Weiss, M. P. Rosynek, J. H. Lunsford, Chem. Commun. 2000, 405; b) V. B. Fenelonov, M. S. Melgunov, I. V. Mishakov, R. M. Richards, V. V. Chesnokov, A. M. Volodin, K. J. Klabunde, J. Phys. Chem. B 2001, 105, 3937.

[18] S. I. Boldish, W. B. White, Spectrochim. Acta 1979, 35, 1235.

[19] J. Holsa, K. Koski, S. Makkonen, E. Sailynoja, H. Rahiala, J. Alloys Compd. 1997, 249, 217.

[20] Y. Hase, P. O. Dunstan, Spectrochim. Acta 1981, 37, 597.

[21] J. Holsa, J. Valkonen, E. Sailynoja, H. Rahiala, Polyhedron 1997, 16, 3421.

[22] B. T. Bowie, D. B. Chase, P. R. Griffits, Appl. Spectrosc. 2000, 54, 164.

[23] B. T. Bowie, D. B. Chase, P. R. Griffits, Appl. Spectrosc. 2000, 54, 200.

[24] Although we have prepared and tested several series of $\mathrm{La}_{2} \mathrm{O}_{3}$ and $\mathrm{LaOCl}$ materials differing in their surface areas, it is very difficult to compare the relative activity of the individual phases, since the materials readily transform from one phase into another due to the surface chlorination/dechlorination reactions and bulk $\mathrm{O} / \mathrm{Cl}$ diffusion.
However, our experiments show conclusively that the $\mathrm{LaCl}_{3}$ phase is inactive for $\mathrm{CCl}_{4}$ decomposition.

[25] Although several attempts to record Raman spectra for the $10 \mathrm{wt} \%$ $\mathrm{La}_{2} \mathrm{O}_{3} / \mathrm{Al}_{2} \mathrm{O}_{3}$ catalyst under reaction conditions were unsuccessful, in some rare cases we were able to resolve weak Raman bands at 337 and $437 \mathrm{~cm}^{-1}$ on top of a fluorescence background. These Raman band indicate the formation of $\mathrm{LaOCl}$ on the support.

[26] K. Nakamoto, Infrared and Raman Spectra of Inorganic and Coordination Compounds Part A: Theory and Applications in Inorganic Chemistry, Wiley, New York, 1997.

[27] C. D. Wagner, Handbook of X-ray photoelectron Spectroscopy, Perkin-Elmer Corp., Eden Prairie, Minnesota, 1979.

[28] V. M. Buznik, L. N. Komissarova, Y. N. Moskvich, G. Y. Pushkina, Zh. Neorg. Khim. 1980, 25, 1488.

[29] J. H. Lunsford, Angew. Chem. 1995, 107, 1059; Angew. Chem. Int Ed. Engl. 1995, 34, 970.

[30] G. J. Hutchings, M. S. Scurrell in Methane Conversion by Oxidative Processes (Ed.: E. E. Wolf), Van Nostrand Reinhold, New York, 1992; K. R. Tsai, D. A. Chen, H. L. Wan, H. B. Zhang, G. D. Lin, P. X. Zhang, Catal. Today 1999, 51, 3.

[31] P. R. Arganbright, W. F. Yates, J. Org. Chem. 1962, 27, 1205.

[32] M. S. Palmer, N. Neurock, M. M. Olken, J. Am. Chem. Soc. 2002, 124, 8452; M. S. Palmer, M. Neurock, M. M. Olken, J. Phys. Chem. 2002, 106, 6543 .

Received: August 13, 2003 Revised: December 8, 2003 [F 5442] 